\title{
Aroylation of aromatics with arylcarboxylic acids over Nafion-H (polymeric perfluoroalkanesulfonic acid), an environmentally friendly solid acid catalyst
}

\author{
G. K. Surya Prakash," Thomas Mathew, Mihirbaran Mandal, Morteza Farnia, and George \\ A. Olah ${ }^{*}$ \\ Loker Hydrocarbon Research Institute and Department of Chemistry, University of Southern \\ California, Los Angeles, CA 90089-1661 \\ E-mail: gprakash@usc.edu, olah@usc.edu
}

\section{Dedicated to Professor P. T. Narasimhan on his $75^{\text {th }}$ birthday}

(received 21 Feb 04; accepted 08 Jan 05; published on the web 15 Jan 05)

\begin{abstract}
Aromatic hydrocarbons undergo direct aroylation with arylcarboxylic acids over Nafion-H, an environmentally friendly, perfluorinated resinsulfonic acid catalyst to give benzophenones and their derivatives. Furthermore, one of the bistrifluoromethylated benzophenone derivative was trifluoromethylated to a new DDT analog.
\end{abstract}

Keywords: Nafion-H, Friedel-Crafts aroylation, benzophenones, ionic liquids, and trifluoromethylated alcohols

\section{Introduction}

Extensive use of a wide variety of alkylating and acylating agents in Friedel- Crafts alkylation as well as acylation, respectively, has been studied. ${ }^{1-3}$ Lewis acids of variable strengths were used. ${ }^{3,4}$ Mechanistic aspects of different Lewis acid catalysed alkylation and acylation have been well studied. ${ }^{5,6}$ Generally, Friedel-Crafts acylation requires molar amounts of the catalyst, which forms complexes with both the acylating agents and the product, carbonyl compounds. ${ }^{7}$ Aqueous workup has been generally used to decompose the carbonyl-Lewis acid complexes, which renders the catalyst in most cases non recoverable. Only extremely reactive aromatics such as thiophenes and substituted thiophenes have been successfully acylated using solid catalysts such as sulfonated polystyrene resins. ${ }^{8}$ Recent advances towards environmentally friendly processes which are economically feasible have shown that ionic liquid systems have great potential for various reactions. ${ }^{9}$ Ionic liquids have been shown to be useful and recyclable catalysts as well as media for Friedel-Crafts acylations. ${ }^{10-12}$ A suitable environmentally benign solid catalyst, which 
can be easily separated and recycled would be highly beneficial. In our recent study, acylation of aromatics has been efficiently achieved using gallium triflate, which is stable to aqueous treatment. $^{13}$

Nafion-H, a perfluoroalkanesulfonic acid resin, has been found to be a suitable solid acid catalyst with high selectivity, and catalytic activity giving good yields of products. ${ }^{14}$ The reaction with Nafion-H conveniently eliminates the use of volatile or noxious reagents. After the reactions with Nafion-H, the catalyst can be easily recovered and regenerated. This solid perfluoroalkanesulfonic acid resin catalyst is more convenient and environmentally friendly in comparison with corrosive acid catalysts (liquid acids) generally used in reactions involving strong acids. Unlike conventional resinsulfonic acids (polystyrenesulfonic acids) such as Dowex50, Amberlyst IR-112 and Permutit-Q, Nafion-H and related perfluroalkanesulfonic acids are not only much stronger acids but are also stable at temperatures up to $200^{\circ} \mathrm{C}$. These unique properties have led to the application of Nafion-H to wide variety of organic reactions such as Friedel-Crafts type electrophilic reactions, synthesis of esters and ethers, various rearrangements etc. ${ }^{14}$ Herein, we report our studies for the convenient intermolecular aroylation of aromatic hydrocarbons using benzoic acids as acylating agents in the presence of Nafion-H as a catalyst.

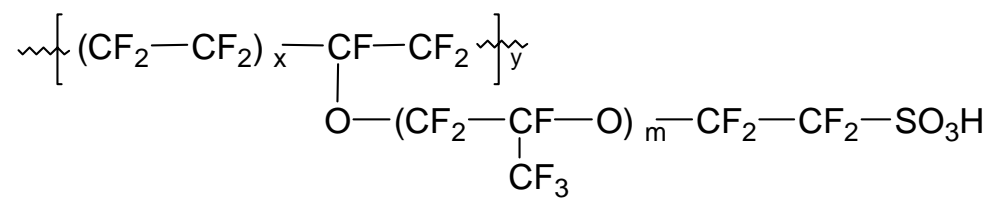

Figure 1. Nafion-H (Solid Resin).

\section{Results and Discussion}

$\omega$-Arylalkanoic acids (1) and their derivatives (2) undergo intramolecular Friedel-Crafts cycliacylation in the presence of Nafion-H, a perfluorinated resinsulfonic acid catalyst. Synthesis of anthraquinone, anthrone, fluorenone and heterocycles such as acridone, xanthone etc. has been achieved in good yields $(>80 \%)$ by this method under the conditions of azeotropic removal of water (Scheme 1). ${ }^{15}$ 


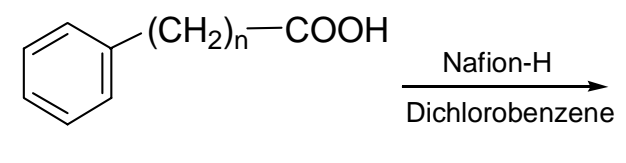

$1(n=2-4)$<smiles>[X]c1ccccc1C(=O)O</smiles>

3

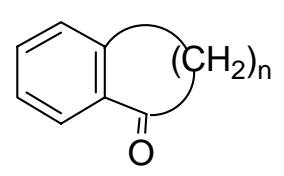

$2(5-92 \%)$

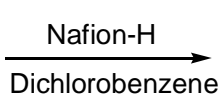<smiles>[X]c1ccccc1C(=O)c1ccccc1[X]</smiles>

$4(82-95 \%)$

$\mathrm{X}=-\mathrm{NH}-,-\mathrm{O}-,-\mathrm{CO}-,-\mathrm{CH}_{2}-$,

Scheme 1. Nafion-H catalysed intramolecular cycliacylation.

Recent studies on direct Friedel-Crafts sulfonylation of aromatics with arene/alkanesulfonic acids (5) showed that Nafion-H acts as a very convenient and efficient catalyst for the preparation of symmetric and unsymmetric diaryl/aryl alkyl sulfones (6). ${ }^{16}$ Nafion-H catalysed acylation of benzene and substituted benzene with aroyl chlorides and anhydrides was described earlier. ${ }^{2}$ However, direct acylation with carboxylic acids have not been explored under these conditions. This prompted us to study direct intermolecular aroylation of aromatics with benzoic acids (7), with azeotropic water removal.

$$
\begin{aligned}
& \underset{\mathbf{5}}{\mathrm{R}-\mathrm{SO}_{3} \mathrm{H}}+\mathrm{Ar}-\mathrm{H} \underset{\mathbf{6}}{\stackrel{\text { Reflux }}{\stackrel{\text { Nafion-H }}{\longrightarrow}}} \underset{\mathrm{R}}{\mathrm{R}}-\mathrm{SO}_{2}-\mathrm{Ar} \\
& \mathrm{R}=\text { alkyl or Aryl }
\end{aligned}
$$

Scheme 2. Nafion-H catalysed direct sulfonylation of aromatics.

Aroylation of activated aromatics afforded the corresponding benzophenones (8) in moderate to good yields (Table 1). However, toluene on benzoylation with benzoic acid gave mixture of benzophenones in only low yield $(<5 \%)$. When the reaction was performed with more reactive thiobenzoic acid, the major product was a mixture of triphenylmethane derivatives $(\sim 15 \%)$.

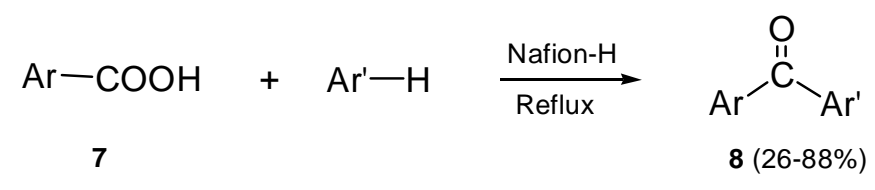

Scheme 3. Nafion-H catalysed aroylation of activated aromatics. 
In all these reactions, the aromatics play the dual role as the substrate as well as the solvent. Reactions were carried out with the corresponding carboxylic acid in excess of the arene under reflux (175-180 $\left.{ }^{\circ} \mathrm{C}\right)$ using a Dean-Stark apparatus for efficient water removal. In the case of toluene the reaction was carried out in a pressure tube at $150{ }^{\circ} \mathrm{C}$. Though benzoylation proceeded faster with thiobenzoic acid, formation of a mixture of ketones and thioketones was observed (GCMS). In the case of anisole, cleavage at the ether linkage followed by benzoylation leads to the formation of phenyl benzoate $(24 \%)$ as a secondary product. In the case of xylenes and mesitylene, side products due to alkylation and dealkylation were also observed. Amount of catalyst varied from 50-100 wt \% with respect to the amount of carboxylic acid used.

Our work was also extended for the preparation of perfluoro derivatives of DDT, which might be more lipophilic and biodegradable. Many studies have been conducted on the structureactivity correlation in DDT analogs. ${ }^{17}$ It has been found that changing substituents at the $\alpha$ position of the ethane bridge greatly affects the activity of the analogs. ${ }^{18}$ Studies of the carbinol analogues on house flies (Musca Domestica L.) show different mode of action. Among the carbinol derivatives studied FDMC (9k) and Dicofol (10) were found to have strong insecticidal activity. The symptoms reported showed increased activity. These carbinols were found to be potent inhibitors of DDT dehydrochlorinase and this explains the minimal resistance of the DDT resistant strains to these carbinols. ${ }^{19}$ At the same time as biodegradability increases, these molecules may tend to build up to a lesser degree than DDT in the environment. 
Table 1. Nafion-H catalysed aroylation of aromatics using benzoic acids

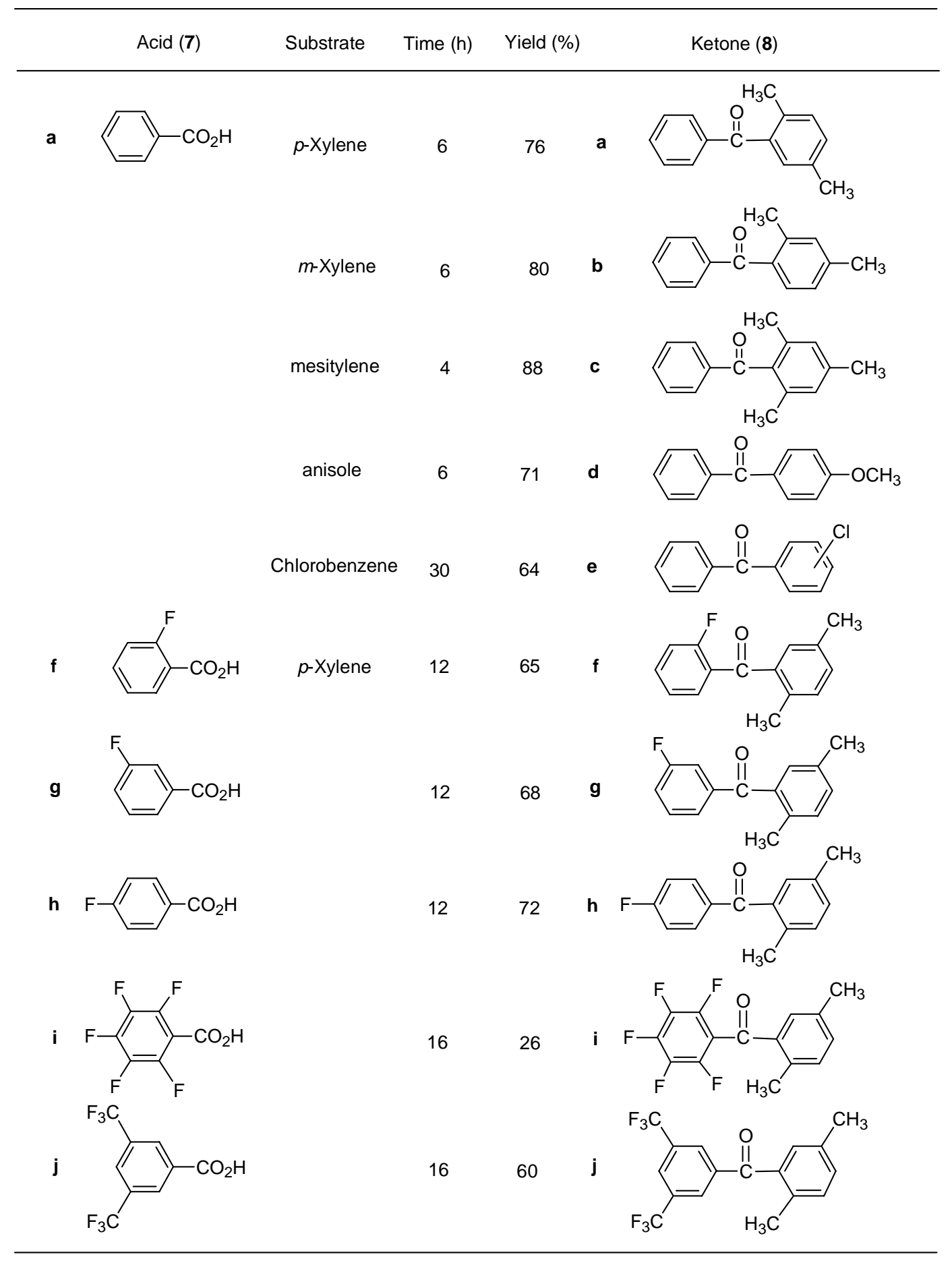

The important role of fluorine in drug molecules in increasing the biological potency of the molecule by better cell penetration, better binding at lipophilic pocket on the receptor and better enzyme activation led us to explore the preparation of fluorinated moieties. We have prepared a number of fluorinated benzophenones (see Table 1). In addition, their direct trifluoromethylation 
using $\mathrm{CF}_{3}$ transfer methodology ${ }^{20}$ with $\mathrm{TMS}-\mathrm{CF}_{3}$ has been adopted to synthesize the perfluoro hydroxy derivative of DDT. For example 3,5-bis(trifluoromethyl)-2',5'-dimethylbenzophenone $\mathbf{( 8 j )}$ gave the corresponding trifluoromethylated alcohol $(\mathbf{9 j})$ in $92 \%$ yield (Scheme 4 ).

The presently developed intermolecular acylation method is a convenient addition to the presently available methods for the synthesis of benzophenones from the corresponding benzoic acids.

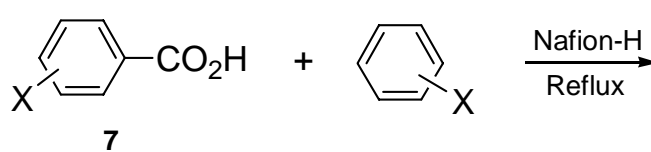

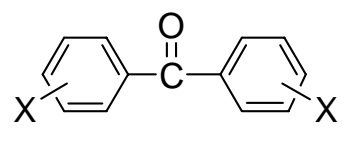

8 TMS-CF $/$ TBAF<smiles>[X]c1ccc(C(O)(c2ccccc2)C(F)(F)F)cc1[X]</smiles>

9

DDT Analogs<smiles>OC(c1ccc(Cl)cc1)(c1ccc(Cl)cc1)C(Cl)(Cl)Cl</smiles>

10

Dicofol<smiles>Cc1ccc(C)c(C(O)(c2cc(C(F)(F)F)cc(C(F)(F)F)c2)C(F)(F)F)c1</smiles>

9i (92\%)

Scheme 4. Synthesis of DDT analogs.

\section{Experimental Section}

General Procedures. Nafion-H was prepared from Nafion-K following the reported procedure. ${ }^{14}$ All arenes were distilled and dried over molecular sieves prior to use. Products were analyzed with a Hewlett-Packard GC-MS (HP-5890 Series II GC coupled with HP-5971 Series MSD, 30 m DB-5 capillary column). Further characterization of the products was carried out by ${ }^{1} \mathrm{H},{ }^{13} \mathrm{C}$ NMR and ${ }^{19} \mathrm{~F}$ measurements using a Varian VXR $300 \mathrm{NMR}$ spectrometer using $\mathrm{CDCl}_{3}$ 
as solvent with TMS (for ${ }^{1} \mathrm{H}$ and ${ }^{13} \mathrm{C}$ NMR) or $\mathrm{CFCl}_{3}$ (for ${ }^{19} \mathrm{~F}$ ) as standard. Melting points were determined using a Mel-Temp II melting point apparatus (Laboratory Devices, Holliston, MA) and are uncorrected. HRMS analyses were performed by UCR Mass Spectrometry Facility, Riverside, California.

\section{Typical benzoylation procedure}

To a solution of dry 3,5-bis(trifluromethyl) benzoic acid $(790 \mathrm{mg}, 5.0 \mathrm{mmol})$ in dry p-xylene (40 mL), Nafion-H (400 mg, $50 \mathrm{wt} \%$ ) was added and stirred. The flask is fitted with a DeanStark trap and the solution was refluxed continuously with stirring for 16 hours (water formed during the reaction was removed completely by introducing dry molecular sieves, $\approx 2.0 \mathrm{gm}$, in the trap). The reaction mixture was filtered and washed with $10 \% \mathrm{NaHCO}_{3}$ solution to remove the unreacted benzoic acid. After washing with water and drying with anhydrous $\mathrm{Na}_{2} \mathrm{SO}_{4}$, excess $p$-xylene was distilled off and the residue was recrystallized from a mixture of dichloromethane and $n$-hexane (1:4) to afford 3,5-bis(trifluromethyl)-2',5'-dimethyl benzophenone as a colorless crystalline solid, (1.0 g, $60 \%)$ m.p. $53{ }^{\circ} \mathrm{C} .{ }^{1} \mathrm{H}$ NMR $\left(300 \mathrm{MHz}, \mathrm{CDCl}_{3}\right): \delta 2.3$ (s, 3H); $2.4(\mathrm{~s}$, $3 \mathrm{H}), 7.2(\mathrm{~s}, 1 \mathrm{H}) ; 7.3(\mathrm{dd}, 2 \mathrm{H}, \mathrm{J}=7.6 \mathrm{~Hz}) ; 8.1(\mathrm{~s}, 1 \mathrm{H}) ; 8.3(\mathrm{~s}, 2 \mathrm{H}) .{ }^{13} \mathrm{C} \mathrm{NMR}\left(75 \mathrm{MHZ}, \mathrm{CDCl}_{3}\right): \delta$ $19.7\left(\mathrm{CH}_{3}\right), 20.74\left(\mathrm{CH}_{3}\right), 122.9\left(\mathrm{q}, \mathrm{CF}_{3}, \mathrm{~J}_{\mathrm{C}-\mathrm{F}}=273.0 \mathrm{~Hz}\right) ; 126.0,129.4,129.9,131.6,132.2(\mathrm{q}$, $\left.\mathrm{C}_{-} \mathrm{CF}_{3}, \mathrm{~J}_{\mathrm{C}-\mathrm{CF}}=34.1 \mathrm{~Hz}\right) ; 132.4,134.5,136.3,139.8,195.5(\mathrm{C}=\mathrm{O}) .{ }^{19} \mathrm{~F}$ NMR $\left(282 \mathrm{MHz}, \mathrm{CDCl}_{3}\right)$ : $\delta$-63.4. HRMS: Calcd. 346.079235. Found 346.078254.

2,5-Dimethyl-2',3',4',5',6'-pentafluorobenzophenone. Colorless crystals, m. p. $97^{\circ} \mathrm{C}$.

${ }^{1} \mathrm{H}$ NMR $\left(300 \mathrm{MHz}, \mathrm{CDCl}_{3}\right): \delta 2.3(\mathrm{~s}, 3 \mathrm{H}) ; 2.60(\mathrm{~s}, 3 \mathrm{H}) ; 7.2-7.3(\mathrm{~m}, 3 \mathrm{H}) .{ }^{13} \mathrm{C}$ NMR $(75 \mathrm{MHz}$, $\left.\mathrm{CDCl}_{3}\right): \delta 20.7\left(\mathrm{CH}_{3}\right), 21.1\left(\mathrm{CH}_{3}\right), 126.8,129.9,132.2,132.4,134.5,135.3,135.8,137.5(\mathrm{~d}, \mathrm{C}-\mathrm{F}$, $\left.\mathrm{J}_{\mathrm{C}-\mathrm{F}}=260.6 \mathrm{~Hz}\right) ; 137.7,142.3\left(\mathrm{~d}, \mathrm{C}-\mathrm{F}, \mathrm{J}_{\mathrm{C}-\mathrm{F}}=257.6 \mathrm{~Hz}\right) ; 143.8\left(\mathrm{~d}, \mathrm{C}-\mathrm{F}, \mathrm{J}_{\mathrm{C}-\mathrm{F}}=256.0 \mathrm{~Hz}\right) ; 186.9$ $(\mathrm{C}=\mathrm{O}) .{ }^{19} \mathrm{~F}$ NMR $\left(282 \mathrm{MHz}, \mathrm{CDCl}_{3}\right): \delta-141.2\left(\mathrm{dd}, \mathrm{J}_{\mathrm{F}-\mathrm{F}}=15.8 \& 6.1 \mathrm{~Hz}\right) ;-151.3\left(\mathrm{t}, \mathrm{J}_{\mathrm{F}-\mathrm{F}}=\right.$ $18.3 \mathrm{~Hz}) ;-160.5$ (m). HRMS: Calcd. 300.057356. Found 300.057470.

Trifluoromethylation with TMS-CF 3 . To 3,5-Bis(trifluromethyl)-2',5'-dimethylbenzo-phenone $(140 \mathrm{mg}, 0.4 \mathrm{mmol})$ dissolved in THF $(3 \mathrm{~mL})$, trifluoromethyl trimethyl silane (TMS- $\mathrm{CF}_{3}$, $143 \mathrm{mg}$; 1mmol) was added. The reaction mixture was stirred and excess of tetra- $n$-butyl ammonium fluoride (TBAF) solution (1 M solution in THF, $2 \mathrm{~mL}$ ) was slowly added. After $1 \mathrm{hr}$ the mixture was quenched with water and extracted with $\mathrm{CH}_{2} \mathrm{Cl}_{2}(2 \times 5 \mathrm{~mL})$. The solution was dried and the solvent was removed by rotary evaporation. The residue on column chromatography (silica gel) using $\mathrm{CH}_{2} \mathrm{Cl}_{2}$ /hexane (1:9) afforded colorless crystals of 3,5bis(trifluoromethyl)-2',5'-dimethyltrifluoromethyldiphenyl-carbinol (155 mg, 92 \%) m. p. $105^{\circ} \mathrm{C} .{ }^{1} \mathrm{H}$ NMR $\left(300 \mathrm{MHz}, \mathrm{CDCl}_{3}\right): \delta 1.8(\mathrm{~s}, 3 \mathrm{H}) ; 2.4(\mathrm{~s}, 3 \mathrm{H}) ; 3.0\left(1 \mathrm{H}, \mathrm{D}_{2} \mathrm{O}\right.$ exchangeable); 7.2 $\left(\mathrm{d}, 1 \mathrm{H}, \mathrm{J}_{\mathrm{H}-\mathrm{H}}=7.9 \mathrm{~Hz}\right) ; 7.1\left(\mathrm{~d}, 1 \mathrm{H}, \mathrm{J}_{\mathrm{H}-\mathrm{H}}=7.9 \mathrm{~Hz}\right) ; 7.5(\mathrm{~s}, 1 \mathrm{H}) ; 7.9(\mathrm{~s}, 3 \mathrm{H}) .{ }^{13} \mathrm{C}$ NMR $\left(75 \mathrm{MH}_{\mathrm{Z}}\right.$, $\left.\mathrm{CDCl}_{3}\right): \delta 20.9\left(\mathrm{CH}_{3}\right), 21.5\left(\mathrm{CH}_{3}\right), 80.1\left(\mathrm{q}, \mathrm{C}_{-} \mathrm{CF}_{3}, \mathrm{~J}_{\mathrm{C}-\mathrm{CF}}=28.3 \mathrm{~Hz}\right) ; 122.8,123.3\left(\mathrm{q}, \mathrm{CF}_{3}, \mathrm{~J}_{\mathrm{C}-\mathrm{F}}\right.$ $=272.83 \mathrm{~Hz}) ; 124.8\left(\mathrm{q}, \mathrm{CF}_{3}, \mathrm{~J}_{\mathrm{C}-\mathrm{F}}=287.2 \mathrm{~Hz}\right) ; 127.9,128.2,130.7,131.7\left(\mathrm{q}, \mathrm{C}_{-} \mathrm{CF}_{3}, \mathrm{~J}_{\mathrm{C}-\mathrm{CF}}=\right.$ $33.6 \mathrm{~Hz}) ; 133.9,134.9,135.3,135.7,141.1 .{ }^{19} \mathrm{~F}$ NMR ( $282 \mathrm{MHz}, \mathrm{CDCl}_{3}$ ): $\delta-74.4,-63.2$. HRMS: Calcd. 416.082269. Found: 416.081480. 


\section{Acknowledgements}

Support of Loker Hydrocarbon Research Institute is gratefully acknowledged.

\section{References and Notes}

1. Yamoto, T.; Hideshima, C.; Prakash, G. K. S.; Olah, G. A. J. Org. Chem. 1991, 56, 2089.

2. Olah, G. A.; Malhotra, R.; Narang, S. C.; Olah, J. A. Synthesis 1978, 672.

3. Olah, G. A.; Meidar, D. Nouv. J. Chim. 1979, 269.

4. Olah, G. A. Friedel-Crafts Chemistry Wiley-Interscience: New York, 1973.

5. McKenna, J. F.; Soma, F. J. J. Am. Chem. Soc. 1937, 59, 1204.

6. Olah, G. A.; Kaspi, J.; Bukala, J. J Org.Chem. 1977, 42, 4187.

7. Norris, J. F.; Aurthur, P. M. J. Am. Chem. Soc. 1940, 62, 874.

8. Norton, T. R. U. S. Patent 1955, 2711414; Chem. Abstr. 1956, 50, 5759.

9. (a) Sheldon, R. J. Chem. Soc., Chem. Comm. 2001, 2399. (b) Welton, T. Chem. Rev. 1999, 99, 2071.

10. Boon, J. A.; Levisky, J. A.; Pflug, J. L.; Wilkes, J. S. J. Org. Chem. 1986, 51, 480.

11. Adams, C. J.; Earle, M. J.; Roberts, G.; Seddon, K. R. J. Chem. Soc., Chem. Comm. 1998, 2097.

12. Gmouth, S.; Yang, H.; Vaultier, M. Org. Lett. 2003, 5, 2219.

13. (a) Prakash, G. K. S.; Yan, P.; Török, B.; Bucsi, I.; Tanaka, M.; Olah, G. A. Catal. Lett. 2003, 85, 1. (b) Prakash, G. K. S.; Yan, P.; Török, B.; Olah, G. A. Synlett 2003, 4, 527. (c) Cui, D.; Kawamura, M.; Shimada, S.; Hayashi, T.; Tanaka, M. Tetrahedron Lett. 2003, 44, 4007.

14. Olah, G. A.; Iyer, P. S.; Prakash, G. K. S. Synthesis 1986, 513 and references cited therein.

15. Olah, G. A.; Mathew, T.; Farnia, M.; Prakash, G. K. S. Synlett 1999, 1067.

16. Olah, G. A.; Mathew, T.; Prakash, G. K. S. J. Chem. Soc., Chem. Comm. 2001, 1696.

17. Fahmy, M. A. H.; Fukuto, T. R.; Metcalf, R. L.; Holmstead, R. L. J. Agr. Food. Chem. 1973, 21,585 .

18. Abernathy, C. O.; Hodgson, E.; Guthrie, F. E. Biochem. Pharm. 1971, 20, 2385.

19. Sawicki, R. M. Nature 1978, 275, 443.

20. Prakash, G. K. S.; Yudin, A. Chem. Rev. 1997, 97, 757 and references cited therein. 